\title{
Practical theology and the call for the decolonisation of higher education in South Africa: Reflections and proposals
}

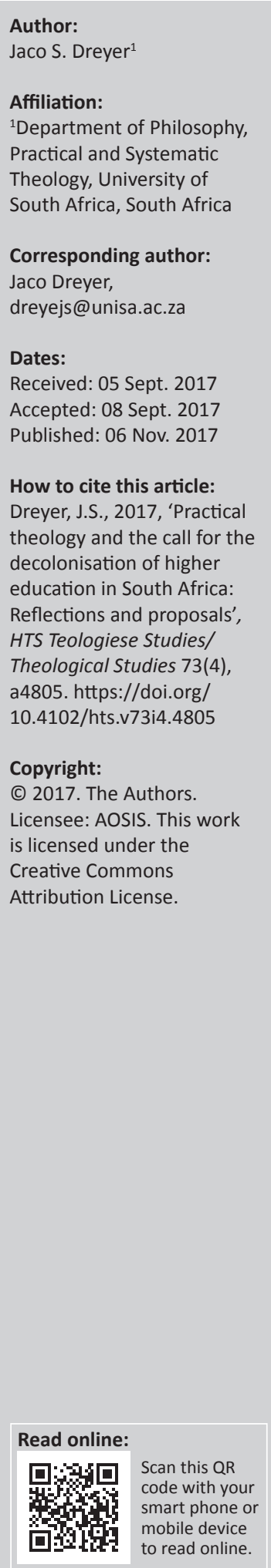

Although the issue of transformation has always been on the agenda of higher education since the transition to a democratic government in 1994, it is only since the student protests in 2015 and 2016 that the call for decolonisation of higher education in South Africa attracted much attention. The aim of this article is to reflect on the discipline of practical theology in South Africa in view of this call for decolonisation. Looking through the theoretical lens of decolonial theory, the author opts for an epistemological perspective on decolonisation. More particularly, the call for decolonisation of knowledge implies a struggle for epistemic justice. With this understanding of the call for decolonisation, the author reflects on the situation of practical theology in South Africa. The article concludes with three proposals for the decolonisation of practical theological research.

\section{Preamble}

It has been a privilege to know and work with Yolanda Dreyer over many years. We have been colleagues in practical theology at neighbouring universities for about two decades, and have served jointly on committees, such as the Executive Committee for the Society of Practical Theology in South Africa and the HTS Editorial Board. We also attended many local and international conferences together. I got to know her as a very sincere person with a particular passion for those on the margins. She has been concerned with a critique of power and the established hierarchies from her early days as pastor, scholar and practical theologian. As a public practical theologian, she tackled many controversial issues and played and continues to play an important role in both the South African and the international practical theological context.

The topic of this article, namely the call for decolonisation of higher education and the possible implications of decolonising knowledge for a South African practical theology, is deliberately chosen for this Festschrift in honour of Yolanda Dreyer. In my view, it is a topic that harmonises well with her research on social justice issues, such as patriarchy, gender violence and different forms of exclusion.

\section{Setting the scene}

Education in South Africa has a history of discriminating theories and practices. The apartheid regime tried to force a foreign and unjust ideology onto the majority of the people of South Africa. The Soweto uprisings of 1976, a result of protests against the language policy in education, is a reminder of the devastating results on the lives of many South Africans. The democratic transition in 1994 brought some changes, but today, more than two decades later, we still see vast inequalities in educational standards, infrastructure, resources and so forth. The inequalities of the school system have many negative consequences for access to higher education (for example, a lack of access to higher education due to poor schooling and low marks). Most South Africans find it very difficult or simply impossible to pay the relatively high tuition fees at our public universities. Although the student profile at the 26 institutions of higher learning in South Africa has changed in the last two decades, it is still far from representative of the demographics of our country. The staff composition has also changed, in some institutions more than in others, but there is still an overwhelming white professoriate at our universities. Although higher education is in the process of transformation, clearly much more has to be done. 
The recent student protests in South Africa do not come as a surprise against the background of the relative lack of transformation in our universities. Moreover, the student protests brought issues to the fore that were hidden in the transformation policies and neglected in practice. One of these issues is the decolonisation of knowledge. ${ }^{1}$ Suddenly the issue of decolonisation was at the forefront of most debates about the restructuring of university education in South Africa. Although the issue of transformation has always been on the agenda of higher education since the transition to a democratic government in 1994, it is only since the \#RhodesMustFall and \#FeesMustFall protests in 2015 and 2016 that the 'call for decolonisation' ${ }^{2}$ attracted much attention. ${ }^{3}$ Since then it became a catchphrase in debates about the restructuring of higher education in this context. ${ }^{4}$ The high number of scholarly articles, debates, inaugural lectures and academic conferences ${ }^{5}$ that focus on the notion of decolonisation since 2015, testifies to the impact of this call for decolonisation on the South African higher education scene.

The aim of this article is to reflect on the discipline of practical theology in South Africa in view of this call for decolonisation. As a first step, we have to explore what is meant by the 'call for decolonisation'. I will argue, with reference to decolonial theory and the interpretation thereof by some South African scholars, that decolonisation in the context of higher education ${ }^{6}$ is best seen in terms of the principles and politics of knowledge, that is, from an epistemological perspective. More particularly, the call for decolonisation of knowledge implies a struggle for epistemic justice (Mungwini 2017). ${ }^{7}$ In view of this understanding of the call for decolonisation, I will next reflect on the call for decolonisation and epistemic justice as a core aspect of decolonisation. Lastly, I will reflect on the challenge of the call for decolonisation for doing practical theological

1The reader may ask whether it is sensible for a white Reformed and male practical theologin to engage with this topic. I am ve much aware of th dangers of writing about decolonisation from my particular social location. I have reflected on this issue in a recent publication (Dreyer 2016) and will not repeat the discussion here.

2.Mbembe (2016:33) writes that the call for decolonisation stretches back many decades: "Calls to "decolonize" are not new. Nor have they gone uncontested whenever they have been made. We all have in mind African postcolonial experiments in the 1960s and 1970s. Then, "to decolonize" was the same thing as "to Africanize". To decolonize was part of a nation-building project.

3.In an article in the Mail \& Guardian Omoyele (2017) writes about 'arrested decolonisation'. He says: 'Perhaps nowhere is the deferral of decolonisation more apparent than in the tertiary institutions'.

4.To the frustration of some academics. Olivier (2016) writes: 'Everywhere one looks today in South Africa you find a new imperative: "Decolonise!" In certain academic quarters it has evidently already attained the level of a new ideology, where quarters ics has (and presumably academics are expected to "decolonise" the courses they teach (and presumably academics do not seem capable of resisting this new ideological drive - for that is exactly what it is: a new ideological movement (albeit a counter-movement) that has the structure of the Biblical requirement, to say "Shibboleth" with the "right" pronunciation, or else ...

5.The theme for the 2017 annual conference of the Society for Practical Theology in South Africa was 'Decolonising practical theology in South Africa'.

6.The university system as such, the existence of disciplines, and so forth are all critiqued by some as remnants of the colonial system. 'Universities have been virtually defined as institutions for the promotion of Western civilization', writes Mazrui (2012:29).

7.'At the core of my argument is the position that there is an epistemic dimension to Africa's problems, and the struggle for epistemic justice is as fundamental to humanity as all other struggles for social justice. Epistemic justice is a corollary of global justice' (Mungwini 2017). research. The article concludes with three proposals for decolonising practical theological research practices.

\section{The call for decolonisation: Decoloniality, knowledge and epistemic justice}

Despite the widespread call for the decolonisation of higher education $^{8}$ in South Africa, we have not reached a common agreement on what this call entails. There seems to be confusion regarding the meaning of 'decolonisation' and the relationship between transformation, Africanisation, indigenisation, and decolonisation. ${ }^{9}$ One way forward, and this is the approach that I opt for here, is to look at decolonisation through the theoretical lens of decolonial theory. ${ }^{10}$ Decolonial scholars emphasise that colonialism in the juridical-political sense has come to an end, but that its legacy continues in many 'colonial situations' where people and groups are oppressed and exploited. Decolonial scholars refer to this enduring legacy of colonialism as 'coloniality' to distinguish it from colonialism as colonial rule under colonial administrations (Grosfoguel 2007). Ndlovu-Gatsheni (2013:37) with reference to Quijano, refers to 'four interrelated domains: control of economy; control of authority, control of gender and sexuality; and, control of subjectivity and knowledge' where the legacy of colonialism in the form of oppression and exploitation continues today. These four dimensions together form the 'colonial matrix of power'. Although these dimensions are interrelated, our focus here is on the last dimension, namely the continuing legacy of oppression and exploitation in the sphere of knowledge. ${ }^{11}$

The 'Western knowledge system'12 developed in Europe during the Renaissance and Enlightenment. It was used to support the colonial administration and to provide legitimacy to the colonial endeavour (Seth 2009). Other cultures and knowledges were seen as inferior to the European knowledge system with its particular constellation ${ }^{13}$ of epistemological, ontological, methodological and axiological presuppositions. This Western science system, with its claim of universality,

8.We limit our discussion here to universities, because universities are at the heart of the struggle for epistemic justice. Pillay (2015) writes: 'Because the university is a place of authoritative knowledge, certified knowledge, it is at the heart of epistemic violence. It is where authorized and legitimate knowledge is cultivated, preserved and protected but also changed."

9.For further reading, see Ndlovu-Gatsheni (2016). He adds a fifth concept, diversification, and calls this the five 'grammars of change'.

10.I do recognise that decolonial theory, with its origin in Latin America and in Latin American liberation theology, is not a 'home-grown' or African theory. Many of the (South) African theorists do, however, follow these leading thinkers, and follow suit.

11.'The control of knowledge and subjectivity through education and colonizing the existing knowledges, which is the key and fundamental sphere of control that makes domination possible' (Tlostanova \& Mignolo 2009:135).

12.I use the notion of 'Western knowledge system' to refer to the institutionalisation and development of scientific knowledge in Europe, and later in other 'First World' contexts, as part of Western modernity, and its continuation in present-day scholarship. I am aware that this is a gross simplification of hundreds of years of development of science in the Western world. This formulation also glosses over the great variety of epistemological, ontological, methodological and axiological constellations within this knowledge system.

13.This constellation of epistemological, ontological, methodological and axiological presuppositions is presented here in the Weberian sense of an ideal type. The many nuances and differences in the day-to-day scientific practices are thus minimised or obscured in this way. 
became part of the colonial rule and research was used as part of the colonisation of non-Europeans. This knowledge system was furthermore presented as a significant part of the 'civilisation' that the colonial powers brought to their

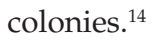

The important point here is that a science system developed in which Europe, and the West, took control of what counts as knowledge. The knowledge produced within this Western knowledgesystemisassumed tobe'universal'and farsuperiorto other knowledges. The decolonial scholar Mignolo (2011) summarises the main features of the epistemology of the Western knowledge system as follows:

\begin{abstract}
... the key concept of coloniality calls into question the idea that knowledge is disembodied and independent of any specific geohistorical locations. The members involved in the project argue that such belief has been created and implanted by dominant principles of knowledge that originated in Europe since the Renaissance.Inorder tobuild a universalconception of knowledge, Westernepistemology (fromChristiantheologytosecularphilosophy and science) has pretended that knowledge is independent of the geohistorical (Christian Europe) and biographical conditions (Christian white men living in Christian Europe) in which it is produced. As a result, Europe became the locus of epistemic enunciation, and the rest of the world became the object to be described and studied from the European (and, later on, the United States), perspective.
\end{abstract}

Decolonial scholars agree, and this is the main point here, that this dominant Western knowledge system continues to structure our understanding of what should be regarded as scientific knowledge, and it continues to exclude, marginalise, and even dehumanise those who see the world otherwise or who have a different view of knowledge and expertise. It is this battle to get rid of the domination of the Western knowledge system and to deal with the 'epistemic wound' that seems to lie at the core of the student protests at universities in 2015 and 2016. These protests highlighted the students' experiences of continuing dominance of the Western knowledge system at our South African universities.

In view of the above we conclude that decolonisation of knowledge means, on the one hand, to challenge and to unsettle this dominant Western knowledge system with its claim of universality and to expose its legacy of epistemic injustice. On the other hand, it means claiming space and legitimacy for other knowledge systems and working towards epistemic justice. ${ }^{15}$

This view of decolonisation in terms of epistemology is not without 'productive tensions' (Harding 2016:11-13). We briefly note three aspects that need to be considered. Firstly, one has to say that this decolonial perspective grossly

14.The idea that science and technology were among the gifts that Western imperial powers brought to their colonies was an integral part of the discourse of the "civilizing mission," one vaunted by both proponents and critics of the methods of colonialism' (Seth 2009:373).

15.As mentioned in the introduction, we restrict our deliberations to the decolonisation of subjectivity and knowledge. It is, however, important to keep in mind that this is just one facet of the colonial matrix of power that we referred to above, and that decolonisation requires the undoing of oppression and exploitation regarding all four elements of the colonial matrix of power. simplifies knowledge practices in the 'Western world'. It glosses over many of the inherent contradictions and tensions and produces an image of a unified scientific approach. This is far from what is happening in actual research practices. In all fairness, one also has to note that the 'decolonial option' is much more nuanced than presented here. Secondly, the decolonial intellectuals who drive this decolonial agenda are all well-established with the science system that they criticise. They write books, travel to conferences and participate in 'normal science'. This makes their work less credible. Thirdly, there are many unresolved tensions in this utopian dream of multiple epistemologies, ontologies, methodologies and axiologies. What will be the outcome of this? Will there be a multitude of 'knowledges' that merely exist next to each other?

When we look at higher education in South Africa through this decolonial lens, it is obvious that our higher education institutions have not yet been decolonised. The education system is still to a large extent dominated by the Western knowledge system and indigenous knowledge systems are still in a marginal position. The indigenous languages have not yet taken their rightful place in institutions of higher learning, and English still dominate in the higher education landscape. Many more examples regarding curricula, pedagogies, research and publication practices could be given to confirm our observation that epistemic justice is but a distant dream.

\section{Practical theology in South Africa and the call for decolonisation}

\section{A historical perspective}

In view of the history of practical theology in South Africa, the recent call for decolonisation of higher education could not have come as a huge surprise for most South African practical theologians. In a chapter on practical theology in South Africa for the Wiley-Blackwell Companion to Practical Theology (2012), I referred to seven challenges for practical theology and practical theologians in South Africa. One of the key challenges, and the one that most clearly reflects the issue of epistemic justice, was stated as follows: 'A second challenge is for practical theology to develop an identity that is distinctively South African. It is often still too dependent on practical theology in the northern hemisphere. This is particularly evident in curricula where prescribed books are mainly from Europe or the USA. More needs to be done to produce handbooks and course material based on the South African context' (Dreyer 2012:513).

Practical theology, as most academic disciplines, has its origin in the European context. The first chair in practical theology was established in Vienna in 1774. Since then it has spread to other parts of Europe and later also to other parts of the world. Heitink (1999), in his now-classic book Practical Theology: history, theory, action domains, describes how practical theology developed against the background of the European Enlightenment. Its institution as an academic discipline was a direct response to the 
secularisation in Europe and the difficulties that churches experienced in adapting to the modern world. Practical theology can therefore be considered as a 'crisis discipline' (Heitink 1999:2). This view is confirmed in the history of practical theology as described by Christian Grethlein and Michael Meyer-Blanck in their book Geschichte der Praktischen Theologie: dargestellt anhand ihrer Klassiker (2000). Although practical theology has since then spread to many other parts of the world, including some postcolonial contexts (South America, Africa), it is still very much tied to its European past. ${ }^{16}$ A quick glance at the Wiley-Blackwell Companion to Practical Theology (Miller-McLemore 2012) or at the membership list ${ }^{17}$ of the International Academy of Practical Theology (IAPT) will confirm this domination. The epistemologies, ontologies and methodologies of practical theologians in 'Southern' contexts are mostly absent from 'international' practical theological books, such as the Wiley-Blackwell companion to practical theology (Miller-McLemore 2012).

Two aspects that confirm the dominance of the 'Western knowledge system' in practical theology can be briefly mentioned. Firstly, the growth of practical theology as an academic discipline in the previous century was, at least partly, due to the new identity of practical theology as a scientific discipline. Practical theology gained a new status in the academic context due to its adoption of the prevailing scientific methods of the social sciences (Van der Ven 1993). Secondly, the 'internationalisation' of practical theology mainly involved practical theologians from Euro-America. This is quite evident in the membership of the scholarly societies and in the publications (journals, book series) that appeared in the last decades of the 20th century.

Practical theology in South Africa developed in a close relationship with practical theology in European countries, such as Scotland, the Netherlands and to a lesser extent, Germany. Local developments closely followed developments in Europe, with an import of ideas through postgraduate studies of South African students at these universities and regular research visits to and from European scholars. ${ }^{18}$ It is only in the last two decades that practical theologians in South Africa slowly started to develop an indigenous (South) African practical theology. The main impetus in this regard came from African students, in particular postgraduate students, who contributed knowledge about the lived

\section{Yang (2012:24) distinguishes three types of psychology: '... indigenous psychology (IP) in Western (Euro-American) countries, and Westernized psychology (WP) and indigenized psychology (IZP) in non-Western nations. Western psychology is the only IP in the world and its hegemonic and powerful transplantation to non- Western societies has resulted in the same kind of WP in almost all of them. Since WP does not correspond to local people and culture and cannot be effectually used to help solve their personal and social problems, increasing numbers of psychologists in many non-Western societies have been trying to convert their WP into a local IZP.' In a similar way, we can say that mainstream practical theology is actually an indigenous practical theology for Euro-American countries.}

17.The problem is that practical theologians from previously colonised or 'Southern' contexts first must become articulate in the language and theories of the dominant (Euro-American) group before they may gain any voice or before they are taken seriously as scholars.

18.It is important to note here that practical theology in the northern hemisphere is also becoming less homogeneous. See for example Opening the field of practical theology (Cahalan \& Mikoski 2014). religion and church practices from an African perspective. However, I reckon that we still have a long way to go to develop a distinctive South African practical theology and to realise the epistemic justice implied by the call for decolonisation. ${ }^{19}$ We too often do (Euro-American) practical theology in Africa rather than practising an African practical theology. ${ }^{20}$

\section{Interlude: Two qualifications}

I would like to make two qualifying thoughts before suggesting concrete steps to be taken in our research practices. Firstly, it is important to note that the drive to decolonise practical theology is not limited to South Africa or even Africa. ${ }^{21}$ The eminent practical theologian Emmanuel Lartey of Emory University has already made an important contribution through his research and publications. His book Postcolonizing God (Lartey 2013) gives concrete examples of decolonising practices. It is also important to note that the hegemony of 'Western science' is not only under siege from so-called third world or developing contexts. There are many practical theologians teaching in strongholds of 'Western science' that call for reforms and new ways of conceptualising the core tasks of practical theology.22 The work of Bonny Miller-McLemore (2016) is a good example in this regard. She forcefully argues for new ways to conceptualise the relation between theory and practice and demonstrates how the dominant intellectual traditions in Western science led to a very narrow understanding of this relationship. We also have to take note about other discourses related to decolonisation. Race has been on the agenda of practical theology for some time now, but the discourse on 'white practical theology' (Beaudoin \& Turpin 2014) indicates a new openness to engage with colonial legacies in practical theology.

Secondly, it is important to add here that practical theology does not only receive the call for decolonisation as a political call for liberation. The motivation to bring about (epistemic) justice is deeply embedded in the core teachings of the world religions and in the Christian religion. It is, therefore, not surprising to practical theologians that decolonial theory is linked to Latin American liberation theology (Harding 2016:3). This does not mean that (practical) theology has an advantage or special position with regards to decolonisation of knowledge. On the contrary, it is a bitter irony that theology and religion

19 A thorough investigation is needed, but from my experience as editor of HTS Practical Theology and from three decades of doing practical theology in South Africa, I can testify to the immense influence of practical theological methodologies Africa, I can testify to the immense influence of practical theological meth
imported from northern hemisphere scholars, especially Osmer (2008).

20.This generalisation does not fully recognise the variety of approaches to practical theology at the different institutions of higher learning. It is difficult to get a good overview due to the relative isolation in which theological education takes place at the different higher education institutions. Closer cooperation should be encouraged We also have a huge variety of theological traditions (evangelical, charismatic, mainline, Pentecostal) in our context, with some of them still very much marginalised in practical theological discourses. I base my observations on the research outputs (rather than the curricula) as these are in the public domain and thus easier to access.

21.It is only fairly recently that decolonial and postcolonial theories started to find some resonance in practical theological scholarship.

22.See, for example, how Michel Andraos (2012) of the Catholic Theological Union in Chicago uses of a decolonial epistemic perspective in the teaching of theology and religion in a context of diversity. 
played such an important role in the legitimation of colonialism and in the building of colonial empires by European states and in the development of apartheid in South Africa. ${ }^{23}$

\section{Responding to the call}

The next step is to consider how practical theology in South Africa could respond to the call for decolonisation of knowledge. We, practical theologians, have to ask ourselves what it means to decolonise practical theology? What can we learn from decolonial theorists regarding decolonisation? ${ }^{24}$ But we also have to think about strategies and implementation of strategies. How can we start implementing decolonial research practices?

I think that practical theologians in academic institutions could start by considering the implications of epistemic (in) justice $^{25}$ regarding each of the core tasks of an academic: teaching, research, community service and academic citizenship. The aim of these deliberations is not to reach a new dogma about practical theology, but rather to form part of an ongoing 'questioning of the processes and norms across the discipline of practical theology' (Radford 2017:3). The decolonisation of higher education is mostly associated with the changing of curricula ${ }^{26}$ (to make it more indigenous and contextual) and pedagogies (that are in tune with the context and liberating) and with research practices (for example, by considering alternative epistemologies, ontologies and methodologies). However, we also have to consider how we plan and implement our community service projects (with others or for others?) and our practices of academic citizenship (for example, who gets invited to do peer reviews). All our academic activities have an ethical dimension and involve questions about epistemic justice. It goes beyond the scope of this article to reflect on all the possibilities and practicalities associated with decolonising these core academic tasks. As a start, I restrict my reflections and proposals to one of these core tasks of academic life, namely that of research or the construction of new knowledge(s). ${ }^{27}$

\section{Decolonising practical theological research}

Practical theological research in South Africa is still very much oriented towards Europe and North America in terms

23. Universities, churches and schools have been the major sites where colonia epistemic violence has been able to masquerade as civilization, progress and development making it the most difficult site to decolonize' (Ndlovu-Gatsheni 2016:8)

24.Theology as a subject area and the different theological disciplines are challenged to engage with this call to decolonise our education. Melinda McGarrah Sharp (2012:423), working within the tradition of postcolonialism rather than decolonial theory, states: '... practical theology as a discipline has not grappled adequately with postcolonial theory and realities.' The same can be said of decolonial theory.

25.'Epistemic injustice gives a name to experiences that we struggle to articulate due to the injuries of hegemonic speech' (Dübgen 2016:1).

26.See for example the work by Le Grange (2011; 2014), Prinsloo (2016) and Van de Westhuizen, Greuel and Beukes (2017).

27.For a similar quest see Radford's very insightful article on postcolonial feminist methodologies in practical theology. She writes: 'This paper seeks to offer necessary troubling of approaches to research in practical theology by exploring how attention to lived experiences of marginalization in post-colonial feminist how attention to lived experiences of marginalization in post-colonial feminist
theologies shapes theological methodologies and attends to the production of theological knowledge' (Radford 2017:1). of its knowledge-generating practices. The dominant epistemologies, ontologies and methodologies are those that are commonly accepted within the Western paradigm of doing research. ${ }^{28}$ The academic journals, societies, scholarships, and leadership positions are very much dominated by the requirements of the prevailing knowledge system. In response to the call for the decolonisation of knowledge, we have to ask ourselves some critical questions. Are we really engaging with local, African issues in ways that are appropriate to and for Africa, or are we imitating the work of northern hemisphere practical theologians? What steps do we have to take to decolonise our research practices? ${ }^{29}$ How could we work towards epistemic justice in our knowledge generating activities? I only briefly mention three proposals, three steps that may help us on the way to implementing decolonisation as a liberating strategy. ${ }^{30}$

A first step is to see the 'bigger picture' by considering the whole research ecosystem. Our research endeavours form part of a large research ecosystem consisting of human capital (for example, the researchers), governance capital (for example, the research policies), physical capital (for example the equipment to do the research or research facilities), intellectual capital (such as knowledge, information and ideas) and lastly financial capital (for example, research grants and funding) (Pandey \& Pattnaik 2015:172). In order to decolonise practical theological research practices, we have to realise that it requires a consideration of all facets of the research ecosystem. This means that we have to attend to aspects such as the funding of research (research grants), the publication of research (who owns and controls publication spaces), access to advanced degrees (who are our postgraduate and postdoctoral students), research networks, ethical practices (issues regarding access, use of research; commercialising research outcomes), language, and so forth. Each element in the research ecosystem has to be considered from the perspective of epistemic justice. Changing the research ecosystem will require a sustained and deliberate approach from everyone.

As a second step towards decolonising our practical theological research practices, I suggest that we fully embrace the humanity of all participants. Some years ago (Dreyer 2007; 2009) I attended to the hermeneutical challenge of participation or belonging in the research process. This seems to me even more important now in view of the call for decolonisation of knowledge. My argument is that empirical research in practical theology requires active and empathetic

28.These distinctions arise from Western philosophies of science and may thus be considered to be part of the problem. Oppong (2016:7) writes in this regard: 'The recent exposure of doctoral students to philosophy of the social sciences without attention to possible African philosophies further deepens the structural hold of Western philosophies on Ghanaian social scientists in general and psychologists in particular.' It will be necessary to consider what science is from the perspective of African philosophies, but this goes beyond the scope of this article.

29.'The word itself, "research" is probably one of the dirtiest words in the indigenous world's vocabulary', in part because research has been a means of embedding the "underlying code" of colonialism across social life' (Smith 1999:1).

30.These questions require a collaborative effort from all the practical theologians in South Africa (and beyond). My ideas here are just presented as a small contribution to a much larger debate that is now taking place and that will continue in the years to come. 
engagement with the lifeworld of the research participants. This entails, among other things, an orientation of utmost respect for the other as a human being, respect for the other's culture, language, traditions, religion, spirituality, and so forth. The immense difficulty of doing practical theological research in a context with so much diversity is obvious. It requires knowledge of these cultural and other practices and a well-developed pastoral sensitivity and personal maturity. The research situation is rife with opportunities that could lead to misunderstanding, the strengthening of stereotypes, and the prolongation of inequality. These pitfalls are intrinsic to all research practices, but gain particular prominence in research in postcolonial contexts.

Participation in the lifeworld of research participants also requires an openness to different epistemologies and ontologies and a critical reflection on the adequacy of our research methods. The research methods that we use must furthermore 'fit' with the epistemologies and ontologies of the research participants. Participatory action research (PAR) and narrative research methods seem to be particularly appropriate, but we also have to consider other decolonial and indigenous research methods. The work by Linda Tuhiwai Smith (1999; see also Denzin, Lincoln \& Tuhiwai Smith 2008) is particularly important in this regard. ${ }^{31}$

Looking through the decolonial lens, I think that the hermeneutical principle of belonging also challenges us to pay specific attention to the notion of privilege. ${ }^{32}$ Who benefits from the research? Who decides on the research questions? Who has the final word in the construction of knowledge? The 'Charter of Decolonial Research Ethics' (Decoloniality Europe 2013) could create awareness of and a sensitivity for the role of privilege in the research process. We also have to consider critically how our privileges in terms of class, gender, race, education, and so forth affect our subjectivity and our positionality in the research process. The notion of belonging also brings the issue of language into play. Can I really participate in your lifeworld if I use my own language? Whose language should be privileged in the research context? These are difficult but important questions to ask in our search for epistemic justice.

The third proposal is to actively and constructively seek to acknowledge the practical knowledge(s) of practitioners. Coolsaet (2016) gives an excellent example of the co-existence and mutual enrichment of distinctive knowledge practices in an article 'Towards an agroecology of knowledges: Recognition, cognitive justice and farmers' autonomy in France'. He describes how different ways of doing and of knowing farming - those of the peasants and those of 'industrial high-input farming' - can be brought together in 'agroecology' of knowledge. The different knowledge systems

31.Stocek and Mark (2009:77-78) give a list of principles for doing indigenous research. The list includes learning about cultural practices, respect, knowledge of local norms, treating participants as equals, and not fostering dependency.

32.We should keep Kendall's (2002:1) warning in mind, namely that it 'is hard to see for those of us who were born with access to power and resources'. Tilley (2017:31) writes in a similar vein that the decolonial scholarly endeavour is burdened by privileges and warns that 'decolonial scholars themselves are snared in the traps they seek to dismantle. are thus not only allowed to co-exist peacefully, but they also participate actively across the different knowledge systems. While reading about these movements that draw their inspiration from decolonial theory, I became aware of the necessity to recognise the practical knowledges of pastors and church leaders who are usually not recognised due to the lack of 'academic rigour', to seek active engagement with these knowledges, on an equal footing, and to co-produce 'situational, environment-specific knowledge'. Practical theologians can contribute to epistemicjustice by participating in such knowledge practices.

\section{Conclusion}

Many questions remain, but it is obvious that practical theologians in South Africa have to respond to the urgent call for the decolonisation of knowledge. Much work lies ahead for all of us to bring about epistemic justice. The steps outlined above could be first, small steps towards a decolonial African practical theology and the healing of the colonial wound.

\section{Acknowledgements Competing interests}

The author declares that she has no financial or personal relationshipswhichmayhaveinappropriatelyinfluencedherin writing this article.

\section{References}

Andraos, M.E., 2012, 'Engaging diversity in teaching religion and theology: An intercultural, de-colonial epistemic perspective', Teaching Theology \& Religion 15(1), 3-15. https://doi.org/10.1111/j.1467-9647.2011.00755.x

Beaudoin, T. \& Turpin, K., 2014, 'White practical theology', in K.A. Cahalan \& G.S Mikoski (eds.), Opening the field of practical theology, pp. 251-269, Rowman \& Littlefield, Lanham.

Cahalan, K.A. \& Mikoski, G.S. (eds.), 2014, Opening the field of practical theology, Rowman \& Littlefield, Lanham.

Coolsaet, B., 2016, 'Towards an agroecology of knowledges: Recognition, cognitive justice and farmers' autonomy in France', Journal of Rural Studies 47, 165-171. https://doi.org/10.1016/j.jrurstud.2016.07.012

Decoloniality Europe, 2013, Charter of decolonial research ethics, viewed 06 June 2017 from http://decolonialityeurope.wixsite.com/decoloniality/charter-of-decolonialresearch-ethics

Denzin, N.K., Lincoln, Y.S. \& Smith, L.T., 2008, Handbook of critical and indigenous methodologies, Sage, London.

Dreyer, J.S., 2007, 'Participation and distanciation in the study of religion', in H.-G. Heimbrock \& C.P. Scholtz (eds.), Religion: Immediate experience and the mediacy of research, pp. 189-211, Vandenhoeck \& Ruprecht, Göttingen.

Dreyer, J.S., 2009, 'Establishing truth from participation and distanciation in empirical theology', in L.J. Francis, M. Robbins \& J. Astley (eds.), Empirical theology in texts and tables: Quantitative, qualitative and comparative perspectives, pp. 3-25, Brill, Leiden.

Dreyer, J.S., 2012, 'Practical theology in South Africa', in B.J. Miller-McLemore (ed.) The Wiley-Blackwell companion to practical theology, pp. 505-514, WileyBlackwell, Oxford.

Dreyer, J.S., 2016, 'Knowledge, subjectivity, (de)coloniality and the conundrum of reflexivity', in J.A. Mercer \& B.J. Miller-McLemore (eds.), Conundrums in practical theology, pp. 90-109, Brill, Leiden.

Dübgen, F., 2016, 'Editorial', Wagadu: A Journal of Transnational Women's and Gender Studies 15, 1-10, viewed 30 August 2017, from http://webhost1.cortland.edu/ wagadu/wp-content/uploads/sites/3/2016/08/v15-Editorial.pdf

Grethlein, C. \& Meyer-Blanck, M., 2000, Geschichte der Praktischen Theologie: dargestellt anhand ihrer Klassiker, Evangelische Verlagsanstalt, Leipzig.

Grosfoguel, R., 2007, 'The epistemic decolonial turn', Cultural Studies 21(2), 211-223. https://doi.org/10.1080/09502380601162514

Harding, S., 2016, 'Latin American decolonial social studies of scientific knowledge', Science, Technology, \& Human Values 41(6), 1063-1087. https://doi.org/ $10.1177 / 0162243916656465$ 
Heitink, G., 1999, Practical theology: History, theory, action domains, transl. R. Bruinsma, Eerdmans, Grand Rapids, MI.

Kendall, F.E., 2002, Understanding white privilege, viewed 03 September 2017, from https://www.cpt.org/files/Undoing\%20Racism\%20-\%20Understanding $\% 20$ White $\% 20$ Privilege $\% 20-\% 20$ Kendall.pdf

Lartey, E.Y., 2013, Postcolonializing God: New perspectives on pastoral and practical theology, SCM Press, London.

Le Grange, L., 2011, 'Challenges for curriculum in a contemporary South Africa', in E. Bitzer \& N. Botha (eds.), Curriculum inquiry in South African higher education: Scholarly affirmations and challenges, pp. 79-91, SunMedia, Stellenbosch.

Le Grange, L., 2014, 'Currere's active force and the Africanisation of the university curriculum', South African Journal of Higher Education 28(4), 1283-1294.

Mazrui, A.A., 2012, From Euro-colonial colleges to the global university: Transition in Muslim and African experience, Unpublished paper, 2 nd draft, viewed 02 September 2017, from https://pdfs.semanticscholar.org/274c/a54d805bdaf0 02 September 2017, from https://p

Mbembe, A.J., 2016, 'Decolonizing the university: New directions', Arts \& Humanities in Higher Education 15(1), 29-45. https://doi.org/10.1177/14740 22215618513

Mignolo, W., 2011, 'Modernity and decoloniality', in Oxford Bibliographies, viewed 02 September 2017, from http://www.oxfordbibliographies.com/view/document/ obo-9780199766581/obo-9780199766581-0017.xml

Miller-McLemore, B.J. (ed.), 2012, The Wiley-Blackwell companion to practical theology, Wiley-Blackwell, Malden.

Miller-McLemore, B.J., 2016, 'The theory-practice distinction and the complexity of practical knowledge', HTS Teologiese Studies/Theological Studies 72(4), 1-8. https://doi.org/10.4102/hts.v72i4.3381

Mungwini, P., 2017, 'The question of epistemic justice: Polemics, contestations and dialogue', in Inaugural lecture at the University of South Africa, Pretoria, August 24.

Ndlovu-Gatsheni, S.J., 2013, Coloniality of power in postcolonial Africa, Myths of decolonization, Codesria, viewed 30 August 2017, from http://www.codesria.org/ spip.php?article1791

Ndlovu-Gatsheni, S.J., 2016, 'Is decoloniality the answer to transformation and Africanization?', paper presented at the Research and Innovation Week, University of South Africa, Pretoria, March 01.

Olivier, B., 2016, '“Decolonisation," the new ideology', Mail \& Guardian, 23 March viewed 30 August 2017, from http://thoughtleader.co.za/bertolivier/2016/03/23/ decolonisation-the-new-ideology/

Omoyele, I., 2017, 'Arrested decolonisation, season 4', Mail \& Guardian, 14 July, viewed 30 August 2017, from https://mg.co.za/article/2017-07-14-00-arresteddecolonisation-season-4
Oppong, S., 2016, 'The journey towards Africanising psychology in Ghana', Psychological Thought 9(1), 1-14. https://doi.org/10.5964/psyct.v9i1.128

Osmer, R.R., 2008, Practical theology: An introduction, Eerdmans, Grand Rapids, MI.

Pandey, S.C. \& Pattnaik, P.N., 2015, 'University research ecosystem: A conceptual understanding', Review of Economic and Business Studies 8(1), 169-181, https:// doi.org/10.1515/rebs-2016-0021

Pillay, S., 2015, 'Decolonising the university', Africa is a Country, transcription of a talk given at Azania House, Bremner Building, University of Cape Town, April 2015, viewed 30 August 2017, from http://africasacountry.com/2015/06/decolonizingthe-university/

Prinsloo, P., 2016, 'Curricula as contested and contesting spaces: Geographies of identity, resistance and desire', Unpublished article based on a presentation at the conference 'Transforming the curriculum: South African imperatives and 21st century possibilities', Pretoria, 01 February, viewed 29 August 2017, from https:// www.researchgate.net/publication/292502252_Curricula_as_contested_and contesting_spaces_Geographies_of_identity_resistance_and_desire

Radford, C.L., 2017, 'Meaning in the margins: Postcolonial feminist methodologies', Practical Theology 10(2), 118-132. https://doi.org/10.1080/1756073X.2017. 1302700

Seth, S., 2009, 'Putting knowledge in its place: Science, colonialism, and the postcolonial', Postcolonial Studies 12(4), 373-388. https://doi.org/10.1080/136 postcolonial', Pos
88790903350633

Sharp, M.M., 2012, 'Globalization, colonialism, and postcolonialism', in B.J. MillerMcLemore (ed.), The Wiley-Blackwell companion to practical theology, pp. 422431, Wiley-Blackwell, Oxford.

Smith, L.T., 1999, Decolonizing methodologies: Research and indigenous peoples, Zed Books, London.

Stocek, C. \& Mark, R., 2009, 'Indigenous research and decolonizing methodologies: Possibilities and opportunities', in J. Langdon (ed.), Indigenous knowledges, development and education, pp. 73-96, Sense Publishers, Rotterdam.

Tilley, L., 2017, 'Resisting piratic method by doing research otherwise', Sociology 51(1), 27-42. https://doi.org/10.1177/0038038516656992

Tlostanova, M. \& Mignolo, W., 2009, 'On pluritopic hermeneutics, trans-modern thinking, and decolonial philosophy encounters', Encounters 1(1), 11-27.

Van der Ven, J.A., 1993, Practical theology: An empirical approach, Kok Pharos, Kampen.

Van der Westhuizen, M., Greuel, T. \& Beukes, J.W., 2017, 'Are we hearing the voices? Africanisa on as part of community development', HTS Teologiese Studies/ Theological Studies 73(3), 4512. https://doi.org/10.4102/hts.v73i3.4512

Yang, K.-S., 2012, 'Indigenous psychology, westernized psychology, and indigenized psychology: A non-western psychologist's view', Chang Gung Journal of Humanities and Social Sciences 5(1), 1-32, viewed 30 August 2017, from http:// memo.cgu.edu.tw/cgihsc/data files $/ 5-1 \% 2001$.pd 